DOI https://doi.org/10.30525/978-9934-588-90-7-43

\title{
СТАТУС ТАКТИК У СТРУКТУРІ \\ НІМЕЦЬКОМОВНОЇ МАКСИМИ НОВОГО ЗАПОВІТУ ТА ПРЕЦЕДЕНТНИХ ОСОБИСТОСТЕЙ
}

\author{
Смоляна Т. А. \\ кандидат філологічних наук, \\ доцент кафедри німецької філології та перекладу \\ Харківський наиіональний університет імені В. Н. Каразіна \\ м. Харків, Україна
}

Об'єктом нашого дослідження є німецькомовна максима - текст або висловлення, які містять узагальнену, глибоку, лаконічну думку певного автора (або народу), із встановленням правил поведінки, основних логічних або етичних принципів, котрими людина керується у своїх вчинках.

Звертаючись до розгляду німецькомовної максими та інструментарію комунікативно-дискурсивного аналізу, ми спираємося на твердження про те, що його основними поняттями є стратегія та тактика.

У нашому дослідженні ми базуємося на вивчення стратегії як «комунікативного наміру мовця, сформованого на основі використання суспільного досвіду для власних та індивідуальних потреб і бажань, i мовна об'єктивізація цього наміру, що надає йому інтерактивного статусу через осмислення вербалізованого наміру всіма суб'єктами, а комунікативної тактики - як мовленнєвої дії (один або декілька мовленнєвих актів), що відповідає першому етапу реалізації комунікативної стратегії і спрямована на розв'язання конкретного комунікативного завдання цього етапу [2, с. 7-11].

3 формальної точки зору, стратегія співвідноситься 3 кількома дискурсивними ходами адресанта, в той час як «реалізація дискурсивної тактики пов'язана з одним ходом, в рамках якого реалізується один або декілька мовленнєвих актів» [1, с. 85].

Суть використання конкретної тактики полягає в тому, щоб змінити конфігурацію параметрів у якомусь напряму: посилити наміри, бажання, трансформувати образ ситуації тощо. Мовленнєва тактика має однакову назву 3 мовленнєвими актами, оскільки вона є мовленнєвою дією, але розглядається не ізольовано, як мовленнєвий акт, а як прийом реалізації мовленнєвої стратегії. Мовленнєву тактику визначаємо як вибір мовленнєвих актів на відповідному етапі спілкування [3]. 
Питання визначення статусу тактик 3 усією очевидністю постає актуальним лише для тих максим, чия структура перевищує одне висловлення, що кореспондує з простим/складним мовленнєвим актом та відповідно репрезентує певну актомовленнєву тактику.

(1) Toren! Hat nicht der, welcher das Äußere gemacht hat, auch das Innere gemacht? Gebt jedoch als Almosen, was darin ist, und siehe, alles ist euch rein.

(Das Neue Testament, Lukas 11:40, S. 167)

Висловлення «Gebt jedoch als Almosen, was darin ist, und siehe, alles ist euch rein» репрезентує основну тактику, оскільки реалізує основну функцію максими - спонукання. Інші висловлення «Hat nicht der, welcher das Äßßere gemacht hat, auch das Innere gemacht?», «Toren!» реалізують допоміжні тактики, вони сприяють обгрунтуванню спонукання шляхом вказівки на те, що кожен має знати, що Господь створив усе, як зовнішнє, так і внутрішнє, а ті, хто цього не розуміє, є дурнями.

(2) Ich freue mich aber über die Ankunft des Stephanas und Fortunatus und Achaikus, denn diese haben eure Abwesenheit ersetzt. Denn sie haben meinen und euren Geist erquickt. Erkennt nun solche an!

(Das Neue Testament, 1 Korinther 16:17-18, S. 398)

У цій максимі висловлення «Erkennt nun solche an!» реалізує основну тактику спонукання, заклик шанувати тих, хто у відсутність певних людей, може не лише їх замінити, але й заспокоювати Святого Духа.

Допоміжні тактики «denn diese haben eure Abwesenheit ersetzt», «denn sie haben meinen und euren Geist erquickt» вказують зокрема причину, 3 якої треба шанувати таких людей, а другорядна тактика «ich freue mich aber über die Ankunft des Stephanas und Fortunatus und Achaikus» створює передумови для реалізації основної тактики.

Серед максим, що за обсягом перевищують одне висловлення, комбінації тактик представлені трьома основними типами, а саме сполученнями:

основна тактика + допоміжна тактика;

основна тактика + другорядна тактика;

основна тактика + допоміжна тактика + другорядна тактика.

Наявність у складі максими в абсолютної більшості випадків однієї основної тактики дозволяє стверджувати, що як максими, котрі за обсягом збіжні з одним висловленням, так і максими більшого обсягу, що містять основну тактику, збіжну з висловленням, передбачають, що це висловлення на формальному рівні може кореспондувати 3 простим або складним реченням. Просте речення в контексті певного мовленнєвого акту становить простий мовленнєвий акт, тоді як складне 
речення складає основу складних мовленнєвих актів, на цій підставі ми розмежовуємо автономні та гібридні мовленнєві тактики.

\title{
Лiтература:
}

1. Безугла Л.Р. Вербалізація імпліцитних смислів у німецькомовному діалогічному дискурсі. Харків, 2007. 332 с.

2. Сковородников А.П. О необходимости разграничения понятий «риторический прием», «стилистическая фигура», «речевая тактика», «речевой жанр» в пратике терминологической лексикографии. Лингвистика. Вып. 5: сб. статей. Смоленск, 2004. С. 5-11.

3. Формановская Н.И. Речевое общение : коммуникативно-прагматический подход. Москва, 2002. 216 с.

DOI https://doi.org/10.30525/978-9934-588-90-7-44

\section{КОНЦЕПТ «CONFINEMENT» У ФРАНЦУЗЬКІЙ ЛІНГВОКУЛЬТУРІ}

\author{
Тарасюк I. B. \\ кандидат філологічних наук, \\ доиент кафедри романської філології і перекладу \\ Запорізький наиіональний університет \\ м. Запоріжжя, Украӥна
}

В умовах пандемії COVID-19 змінюється ситуативний контекст спілкування (у термінах Ф.С. Бацевича [1, с. 337]) - обставини, у яких відбувається комунікація. Оскільки на перший план виходить феномен «confinement» - ізоляція, усамітнення, стримування, то по-новому організуються час та місце спілкування, по-новому осмислюються соціальні ролі учасників комунікації.

У французькій мові лексема confinement має три значення: 1) застаріле ізоляція (ув'язненого) - vieilli. Isolement (d'un prisonnier); 2) факт або дія вилучення, замикання (у вузьких межах) - Fait d'être retiré; action d'enfermer, fait d'être enfermé (dans des limites étroites); 3) біол. утримання живої істоти (тварини або рослини) в обмеженому та закритому середовищі - BIOL. Maintien d'un être vivant (animal ou plante) dans un milieu de volume restreint et clos [2]. Як бачимо, концептуальна або когнітивна карта (в термінах О.С. Кубрякової [3, с. 373]) французького слова confinement організована навколо концептів «isolement» («ізоляція»), 